\title{
Study on Ecological Classroom Teaching Methods of College English Listening and Speaking in Internet Plus Era
}

\author{
Juxiang Wen \\ College English Teaching Department \\ Zaozhuang University \\ Zaozhuang, China
}

\begin{abstract}
In Internet plus era, the course of college English listening and speaking is encountering great opportunities and challenges, and is increasingly being combined with the modern information technologies. This paper discusses the imbalance of the three ecological factors in the ecological classroom of college English listening and speaking, analyzes its reason and try to find out some useful methods to construct the balanced ecological classroom of college English listening and speaking from the perspective of ecology. Some meaningful suggestions are put forward for Ecological classroom of College English listening and speaking, such as, improvement of teachers' and students' the information technology literacy, construction of diversified effective evaluation system, innovation of teaching philosophy and so on, which is based on the theory of education ecology and review of teaching activities from the interdisciplinary perspective of ecology classroom.
\end{abstract}

Keywords-ecological classroom; Internet plus era; college English listening and speaking; ecological factors

\section{INTRODUCTION}

In 1976, Laurence $\bullet A \cdot$ Cremin, the professor in Columbia University put forward the concept of education ecology and the philosophy of Ecological Class Balance, which provides a new perspective of educational research. Education Ecology consists of the basic ideas of ecology. [1]Therefore, educators can systematically re-examine the teaching activities on the whole. In1980s, the concept of education ecology was introduced to the field of education. Ecological Classroom is a dynamically balanced, open and orderly micro ecological system, which is made up of teachers, students and classroom environment. According to the concept of Ecological Classroom, we can analyze and solve the complex teaching problems from the perspective of ecology. Ecological Classroom also refers to the class that respects the rule of education and teaching, and students' characteristics of physical, mental and cognitive development, and reflects the students' individual and all-round development needs, and their life vitality. When constructing ecological classroom, teachers need get rid of the view of mechanical teaching, give classes in accordance with the student-centered principle, and establish the dynamic class full of the interaction between the teacher and students, and the interaction among the students. Therefore, three factors of the teacher, student and the environment interact with each other, which reflect the overall linkage of students and the teacher, teaching and learning, and people and environment.

Internet plus era speeds up the reform of education, especially English teaching mode, promotes the innovation of the teaching process and improves the optimal allocation of educational resources. However, some of the unbalanced phenomena appeared when modern information technology, especially computer network technology is integrated with English teaching. [2]The education ecology provides theoretical guidance and practical methods in order to eliminate the ecological imbalance of College English class and construct harmonious ecological classroom. This is because English classroom is like a micro ecological system in accordance with the education ecology and the system keeps a relative balance through the integration of the three factors - students, the teacher and environment during the long-term teaching practice. Therefore, how do the educators solve the problem of imbalanced phenomena when modern information technology is applied to college English teaching? How do teachers build balanced ecological classroom from the new perspective of education ecology? These questions need to be thought about deeply.

\section{ECOLOGICAL IMBALANCE OF COLLEGE ENGLISH LISTENING AND SPEAKING IN INTERNET PLUS ERA}

Based on the theory of ecology, education ecology learns from and adopts research methods of the two subjects of pedagogy and ecology, and study the relationship between various ecological factors and education in the ecological environment in order to promote the harmonious, balanced and sustainable development of education. Therefore, education ecology offers proper theories and methods for educators to discover, analyze and solve the classroom ecological imbalance during the integration of modern information technology and English teaching, and to build a harmonious ecological classroom. Although the modern information technology teaching reform in Internet plus era has greatly promoted the development of the ecological system of college English teaching, in the construction of ecological system in the process of English teaching, the new teaching system is 
disturbing the ecological balance of the original class teaching, and some imbalances appear.

\section{A. Imbalance of Ecological Classroom Environment}

According to the education ecology's principle of the most appropriate and tolerance law, the former means the influence of ecological factors needs not to be out of the most proper range, which is the balanced result of quality and quantity of the ecological factors, and the latter means the degree of the ecological factor' tolerance in quality or quantity of tolerance, which refers to the ecological factor of various complex conditions the animals depend on. [3] These two factors are limited. Both "more" and "less" are harmful. Nowadays, many college English listening and speaking classroom environment violates the rules of education ecology. There are too many students in class, which is beyond the tolerance and endurance of the ecological classroom. On the one hand, if the class size is too large, the classroom space will be occupied, and can't be divided into different areas in order to meet students' different needs. On the other hand, if there are a large number of students, it will be difficult for the teacher to completely understand the individual characteristics of each student, and to create the proper conditions for the development of individual students. At the same time, teachers and students will have psychological pressure caused by such a large class, and thus it's difficult for them to achieve effective interaction and perform classroom activities. It finally causes probably a serious imbalance of teachers and students, and classroom environment, which seriously prohibits the healthy and orderly development of classroom ecosystem. As multi-media are widespread and popular among college English teaching class, the curtains are always kept closed even in the break time, which makes it dark and many students are sleepy and couldn't focus on learning. The desks in many classrooms are fixed to the floor, and put together line by line according to the traditional way, which is not suitable for group discussion and interaction between the teacher and students.

\section{B. Imbalanced Students' Status in College English Listening and Speaking}

Now, many teachers still adopt the traditional teaching mode in many colleges and universities. In this way, the teachers inculcate too much in class and give the same standard teaching material. [4] And the students are required to accept the content, the teaching mode, progress, evaluation methods of the course and so on. In such a teaching mode, teachers are still the main body of the class, and students receive knowledge passively, and have no opportunity of participation and practice. The dislocation of the roles of teachers and students affects students' enthusiasm to take part in. At the same time, teachers couldn't get timely feedback, improve teaching methods, and the teaching effect will be greatly reduced too. In Internet plus era, with the application of computers and multimedia teaching methods, teachers rely too much on the rich and complete electronic teaching materials, and lack deep thinking about teaching materials and teaching design. If that continues, teachers' professional development will be restricted as well.

\section{THE REASON OF IMBALANCED ECOLOGICAL COLLEGE ENGLISH LISTENING AND SPEAKING CLASSROOM}

The students are easy to lose heart and confidence in the inculcating traditional teaching method for a long time. NonEnglish majors' English level and communicative ability can be showed directly by their listening and speaking ability. The evaluation standard of their work department is the most effective one in practice to assess the quality of the course.

In Zaozhuang University, one of the application-oriented universities, many students come from the rural regions, and the English score of most students is or lower than the average one. Meanwhile, college students have many courses about their major need to take and lack time and energy to master the language tool especially for non-English majors. There are many imbalanced situations in college English listening and speaking classroom such as imbalanced ecological classroom environment, imbalanced roles of the teachers and students, imbalanced situation of examination-oriented education and comprehensive development of students, imbalanced learning content of giving and taking, imbalanced situation of learning motivation and result. The strategies of teaching and learning are not effective enough. There is a great gap between the teaching method of listening and speaking classroom and current demand. [5] The applicators couldn't communicate well with the clients in a foreign language so the job interviewers have a negative attitude toward college graduates' English ability.

Opportunities and challenges are faced by College English listening and speaking in Internet plus era. Internet plus has brought a large amount of resources to college English teaching. According to the statistic, information in English is up to $90 \%$ in the international Internet. There are various types of teaching resources such as official education resources, teachers' personal website, e-book, digital libraries and so on. Students can learn English in their individual flexible ways in Internet plus era. It's beneficial for English learners and makes them easily get rid of the limit of time and space. They can arrange their learning in accordance with their own situation and pace. Therefore, the individualized education and teaching in accordance with students' aptitude can be actualized. Students become the real master of their learning. The centered status of their learning has come back as well and they are active and positive in English learning. Last but not least, the use of modern information technology improves the relationship between the teacher and students, and strengthens the communication among students.

The influence of Internet plus to college English listening and speaking teaching is revolutionary. The use of modern information technology in college English teaching has brought wide space to the development of teaching. The process of teaching reform is full of challenges as well. First, the teacher needs to acquire the knowledge of various modern information technologies and also needs to master and use it skillfully to the real teaching of college English teaching. The teacher needs to become the guiders of students, the cooperator and the consulter from the initiator and supervisor in the traditional way. Second, online teaching technology needs students to have high autonomous learning ability, and needs them to 
make full use of various online resources online to actively discover, discuss and construct knowledge. Last, information technology will change the traditional evaluation method of teaching that only pays attention to students' summative assessment to the comprehensive assessment which combines process evaluation with developmental evaluation. This means that the educators can improve the teaching quality and students' comprehensive development through adopting various assessment methods in order to evaluate the teaching aim, teaching process, and teaching information. Therefore, it's easy to find that the combination of Internet plus and college English teaching demands higher requirement of teaching process and assessment system. [6]

\section{THE StRATEGIES OF BALANCED DEVELOPMENT OF ALL THE ECOLOGICAL FACTORS}

In college English listening and speaking classroom, if there are no effective methods, it's difficult to change the current situation and improve students' comprehensive English ability. The author try to discuss and analyze the problems existed in college English listening and speaking classroom, and find out some useful methods or teaching modes.

The strategies of balanced development of all the ecological factors of college English listening and speaking classroom in Internet plus era. Ecological balance is a situation of relative and dynamic balance in which biological genes, species and diversity of ecological system keep a relative balance. The number of each species will keep a natural balance in the ecological system. Ecological classroom system is very similar to the natural ecological system to a certain degree. The three ecological factors of ecological classroom system, the teacher, students and teaching environment, they rely on each other, and have a great influence on each other. However, the ecological structure of college English listening and speaking classroom needs to be optimized.

The proper teaching philosophy and principles of College English Listening and Speaking need to be taken. College English teachers take students as the main body of learning and aim at cultivating students' comprehensive ability especially the listening and speaking ability. In modern education mode the teachers need to emphasize the cultivation of students' autonomous learning ability and their innovation ability in the whole English teaching process.

The information technology literacy of teachers and students needs to be improved. In Internet plus era, both teachers and students should acquire some knowledge of information technology, and it is also an important factor in information reform of English teaching. First of all, college English teachers need to learn and spread the advantages of information technology teaching through watching information teaching demonstration and taking professional training courses. Secondly, the corresponding evaluation mechanism, supervision mechanism and incentive mechanism need to be made in order to monitor and supervise the information behavior of teachers and students.

The flexible teaching methods need to be adopted. In Internet plus era, proper teaching methods should be taken in accordance with the concrete teaching situation in order to improve the effectiveness of the whole classroom teaching. For example, the aim of the course, the purpose of a one period, the whole situation of the class, students' individual difference, the learning atmosphere, teaching environment and so on could be the important factors for the teacher to consider, in order to make a teaching plan and change the teaching methods.

Suitable textbooks or teaching materials need to be chosen. The teacher must choose textbook and teaching materials suitable for students' major and ability. For students, the textbook or other kinds of teaching materials are the important link with the teacher. Therefore, the election of the textbook or teaching materials needs to be paid attention to in order to meet the students' need.

Diversified effective evaluation system needs to be constructed. [7]The reform of evaluation methods will show the characteristic of college English listening and speaking, and is helpful to improve students' listening and speaking ability. The teacher can take diversified evaluation methods for the process assessment. The evaluation of the learning process is added to college English listening and speaking. Only one time of listening test or oral test for each semester is changed. For college English listening and speaking classroom in the Internet era, the evaluation of teaching and learning plays an important role in the supervision of the teaching quality. The modern information technology is a useful platform to collect the feedback information and provides suggestions to monitor the teaching and learning behaviors. On one hand, the educators need to effectively evaluate the evaluation of teaching aim and function, the main body, people, content, principle, and approach of the evaluation. On the other hand, the purpose of the evaluation needs to be helpful to the ecological factors' development. The proper evaluation methods, approach and content need to be adopted in order to more effectively show the ecological function of the diversified evaluation system.

\section{CONCLUSION}

The college English teachers need to not only create their teaching thought but also need to bravely reform the classroom environment, improve the information literacy of themselves and students, and adopt the suitable teaching methods because of the huge advantages brought up by the application of modern information technology to college English listening and speaking classroom in Internet plus era. The real combination of Internet, information technology English teaching is needed to construct the interactive and open ecological classroom of college English listening and speaking there are some imbalanced situations because of the application of modern information technology to English teaching.

\section{REFERENCES}

[1] Chen Yuming, "A shallow discussion on eco-teaching about college English listening and speaking based on flipped classroom," Journal of Hubei Normal University, 2017(1), pp. 111-115.

[2] Li Ming and Cai Jigang, "College English teaching reform to cope with a transition- an interview with Prof. Cai Jigang," Shandong Foreign Language Teaching Journal, 2013(5), pp.3-6. 
[3] Li Hongmei, "Construction of ecological environment in network-based college English teaching," Journal of Heilongjiang College of Education, 2012(11), pp183-185.

[4] Liu Yongli, "The scientific orientation of Ecological Role of teachers in college English teaching," Theory and Practice of Education, 2017(18), pp31-32.

[5] Wu Hanqing and Sun Mu, "The construction of ecological classroom," Theory and Practice of Education, 2017(2), pp. 3-6.

[6] Cui Nan and Wu Zhongwen, "On the application of MOOC in college English teaching," Journal of Inner Mongolia Agricultural University, 2017(3), pp75-79.

[7] Hu Wang and Yang Cheng, "Technology, learning and educational innovation: the opportunities and challenges of educational technology: the review of the 14th international forum on education technology in 2015” Lifelong Education Research, 2016(1), pp59-64. 